\title{
Seminal fluid anaphylaxis
}

\author{
Mariam Deria ${ }^{1 *}$, Caroline Rizk², Joanne Desormeaux ${ }^{4}$, Stephanie Santucci ${ }^{4}$, Jacob Karsh ${ }^{2}$, Jonathan Bernstein ${ }^{3}$, \\ William H Yang ${ }^{2,4}$
}

From Canadian Society of Allergy and Clinical Immunology Annual Scientific Meeting 2011

Quebec, Canada. 20-23 October 2011

\section{Background}

Seminal Fluid Anaphylaxis (SFA) is a rare condition caused by IgE mediated sensitization to seminal proteins during or after coitus. It has been reported about 80 times in the medical literature ranges in symptomatology from local pruritus to serious systemic reactions. This is the first known documented case in Canada.

\section{Methods}

One case is presented including clinical course and positive skin prick testing to husband's seminal fluid after consultation with an allergist and obtaining written consent.

\section{Results}

A 54 year-old woman with no atopic history was referred for evaluation after four progressive episodes of post-coital reactions with her husband. The first two episodes consisted of itching of both palms and soles of feet with minimal vaginal pruritus. After abstaining, a third episode a month later consisted of hives on the patient's legs and back with significant vaginal pruritus. The fourth episode the patient developed vaginal and generalized pruritus, urticaria, palpitations and trouble breathing through her nose, immediately post-coital. All symptoms resolved spontaneously with no treatment. Skin prick testing was conducted using the partner's seminal fluid to confirm the clinical suspicion of SFA, producing a wheal of $8 \mathrm{~mm}$ and flare of $5 \mathrm{~cm}$.

\section{Conclusions}

The partner's seminal fluid will be fractionated to determine the specific amino acid sequence of interest by serum-specific IgG/IgE by ELISA to the seminal plasma and plasma proteins. An SDS-PAGE and IgE immunoblot assay will confirm specific activity to the semen. Of clinical

${ }^{1}$ McMaster University, Hamilton, Ontario, Canada

Full list of author information is available at the end of the article relevance, mass production of this protein will be used for local or systemic immunotherapy to prevent future SFA.

\section{Author details}

${ }^{1}$ McMaster University, Hamilton, Ontario, Canada. ${ }^{2}$ University of Ottawa, Ottawa, Ontario, Canada. ${ }^{3}$ University of Cincinnati, Cincinnati, Ohio, U.S.A. ${ }^{4}$ Allergy \& Asthma Research Centre, Ottawa, Ontario, Canada, K1Y 4G2.

Published: 14 November 2011

doi:10.1186/1710-1492-7-S2-A39

Cite this article as: Deria et al: Seminal fluid anaphylaxis. Allergy, Asthma \& Clinical Immunology 2011 7(Suppl 2):A39.
Submit your next manuscript to BioMed Central and take full advantage of:

- Convenient online submission

- Thorough peer review

- No space constraints or color figure charges

- Immediate publication on acceptance

- Inclusion in PubMed, CAS, Scopus and Google Scholar

- Research which is freely available for redistribution
() Biomed Central
() Biomed Central

C 2011 Deria et al; licensee BioMed Central Ltd. This is an open access article distributed under the terms of the Creative Commons Attribution License (http://creativecommons.org/licenses/by/2.0), which permits unrestricted use, distribution, and reproduction in any medium, provided the original work is properly cited. 